\title{
Transfer of Hyphomicrobium indicum to the genus Photobacterium as Photobacterium indicum comb. nov.
}

\author{
Correspondence \\ Cheng-Hui Xie \\ aa37116@mail.ecc.u-tokyo.ac.jp
}

\author{
Cheng-Hui Xie and Akira Yokota
}

Institute of Molecular and Cellular Biosciences, The University of Tokyo, 1-1-1, Yayoi, Bunkyo-Ku, Tokyo 113-0032, Japan

\begin{abstract}
Hyphomicrobium indicum Johnson and Weisrock 1969 lacks true budding and hyphal branching and some phenotypic characteristics are in contrast to other true hyphomicrobia. The major quinone system (ubiquinone $\mathrm{Q}-8$ ), the $\mathrm{G}+\mathrm{C}$ content of the DNA (40 mol\%) and the cellular fatty acid composition $(16: 0,16: 1$ and $18: 1$ as the major components, and 12:0 3-OH and $14: 03-\mathrm{OH}$ as the hydroxy fatty acids) of $H$. indicum are different from the genus Hyphomicrobium, but similar to the genus Photobacterium. Like the marine bacteria Photobacterium, H. indicum can be tolerant of sea water, while Hyphomicrobium cannot. Phylogenetic analyses of $16 \mathrm{~S}$ rRNA and gyr $B$ gene sequences revealed that $H$. indicum is most closely related to the genus Photobacterium of the $\gamma$-Proteobacteria. Based on the phylogenetic, phenotypic and chemotaxonomic evidence, the results indicate that $H$. indicum should be transferred to the genus Photobacterium, and the name Photobacterium indicum comb. nov. (type strain, NBRC $14233^{\top}=$ ATCC $19614^{\top}$ ) is proposed.
\end{abstract}

The genus Hyphomicrobium Stutzer and Hartleb 1898 contains budding or appendage bacteria that can form various kinds of cytoplasmic extrusions: hyphae or appendage (prosthecate). A comprehensive review of the taxonomy, physiology and ecology of budding bacteria was given by Hirsch (1974). Based on 16S rRNA gene sequence analysis, Hyphomicrobium species were classified as members of the $\alpha$-subclass of the Proteobacteria and showed a heterogeneous phylogenetic relationship (Stackebrandt et al., 1988; Roggentin \& Hirsch, 1989; Tsuji et al., 1990, Rainey et al., 1998). These facultatively methylotrophic bacteria can grow well on methanol, monomethylamine, chloromethane and some other $\mathrm{C}_{1}$ compounds. Many investigations have revealed evidence indicating that these bacteria play an important role in the bacterial community structure of activated sludge of wastewater treatment, and novel species have recently been isolated from soil, swamp sludge and freshwater by using the special medium for Hyphomicrobium species (Borodina et al., 2002; Layton et al., 2000; McDonald et al., 2001; Holm et al., 1996). To our knowledge, however, Hyphomicrobium indicum has not been isolated from these ecological environments and cannot grow on the special medium for hyphomicrobia, therefore indicating that it is not a methylotrophic

Published online ahead of print on 7 May 2004 as DOI 10.1099/ ijs.0.63159-0.

The GenBank/EMBL/DDBJ accession number for the 16S rRNA gene sequence is $A B 159513$ and that for the gyrB sequence is $A B 159514$. bacterium. H. indicum has not been studied by phylogenetic analysis since it was proposed by Johnson \& Weisrock (1969). In Bergey's Manual of Systematic Bacteriology, the placement of $H$. indicum within the genus Hyphomicrobium is questioned by Hirsch (1974) because some phenotypic characteristics are in contrast to those of other true hyphomicrobia. The intent of the present study was to elucidate the phylogenetic relationship of $H$. indicum based on 16S rRNA gene, gyrB gene and chemotaxonomic characteristics.

H. indicum NBRC $14233^{\mathrm{T}}$ was obtained from the culture collection of NBRC (NITE Biological Resource Center, Chiba, Japan) and cultured on medium (10 g peptone, $2 \mathrm{~g}$ yeast extract, $0.5 \mathrm{~g} \mathrm{MgSO}_{4} .7 \mathrm{H}_{2} \mathrm{O}, 750 \mathrm{ml}$ sea water, $250 \mathrm{ml}$ distilled water) at $24^{\circ} \mathrm{C}$. Cellular fatty acid methyl esters were prepared, separated and identified using the Microbial Identification system as described by Xie \& Yokota (2003). The respiratory quinone system was extracted and determined by HPLC (Shimadzu), and the genomic DNA extraction, PCR-mediated amplification of the 16S rRNA gene and sequencing of the PCR products were carried out as described previously (Xie \& Yokota, 2003), and a 1412 bp 16S rRNA gene sequence of $H$. indicum NBRC $14233^{\mathrm{T}}$ was determined. PCR-mediated amplification of $\operatorname{gyr} B$ and sequencing of the PCR products were carried out as described by Yamamoto \& Harayama (1995), and a 1137 bp gyrB sequence of $H$. indicum was determined. The DNA sequences of $H$. indicum NBRC $14233^{\mathrm{T}}$ were compared with the sequences obtained from the DNA database. The 
Table 1. Phenotypic characteristics of $H$. indicum and the reference strains of the genera Photobacterium and Hyphomicrobium

Strains: 1, Photobacterium profundum; 2, P. phosphoreum; 3, Hyphomicrobium vulgare; 4, H. indicum. Some data were from Johnson \& Weisrock (1969) and Nogi et al. (1998). All of these species are motile and L-arabinose cannot be utilized. ND, Not done; NT, lack true budding and hyphal branching.

\begin{tabular}{|c|c|c|c|c|}
\hline Characteristic & 1 & 2 & 3 & 4 \\
\hline Quinone & Q-8 (95\%), Q-7 & Q-8 & Q-9 & Q-8 \\
\hline Optimum growth temperature $\left({ }^{\circ} \mathrm{C}\right)$ & 18 & 10 & 30 & 25 \\
\hline Sea-water tolerance & + & + & - & + \\
\hline Gas produced with growth on the glucose & - & + & ND & + \\
\hline Catalase & + & + & - & - \\
\hline Oxidase & + & + & - & - \\
\hline Production of $\mathrm{H}_{2} \mathrm{~S}$ & - & - & - & + \\
\hline Production of indole & + & - & - & + \\
\hline Nitrate reduced & + & + & + & + \\
\hline Lysine decarboxylase & - & - & $-1+$ & - \\
\hline \multicolumn{5}{|l|}{ Carbon utilization } \\
\hline Maltose & + & + & - & + \\
\hline Sucrose & - & - & - & + \\
\hline $\mathrm{G}+\mathrm{C}$ content $(\mathrm{mol} \%)$ & 42 & 39 & 61 & 40 \\
\hline Budding formation & - & - & + & NT \\
\hline
\end{tabular}

sequences were aligned using the CLUSTAL W software package (Thompson et al., 1994), and the evolutionary distances and $K_{\text {nuc }}$ value (Kimura, 1980) were generated. Alignment gaps and ambiguous bases were not taken into consideration when the 16S rRNA gene (1262 bases) and $g y r B$ (1134 bases) nucleotides were compared. The phylogenetic trees were constructed using the neighbourjoining method (Saitou \& Nei, 1987). The topology of the phylogenetic tree was evaluated by the bootstrap resampling method of Felsenstein (1985) with 1000 replicates. The similarity values were calculated using PAUP $4.0684 .0 \mathrm{~b} 1$ (Swofford, 1998). The 16S rRNA gene sequences determined in this study were submitted to GenBank/EMBL/DDBJ with the following accession numbers: AB159513 (16S rRNA gene) and AB159514 (gyrB).

The phenotypic characteristics of $H$. indicum compared with the reference strains of the genera Photobacterium and Hyphomicrobium are shown in Table 1. The cells of Hyphomicrobium release buds from the ends of long and thin hyphae, but $H$. indicum lacks true budding and hyphal branching, demonstrating a pleomorphic shape (Hirsch, 1989), while Photobacterium cells are rod-shaped. The major quinone system of $H$. indicum is ubiquinone Q-8, which is the same as genus Photobacterium but different from Hyphomicrobium (Q-9). H. indicum, like the marine bacteria of the genus Photobacterium, can be tolerant of sea water, while other Hyphomicrobium species cannot. The $\mathrm{G}+\mathrm{C}$ content of the DNA of $\mathrm{H}$. indicum is $40 \mathrm{~mol} \%$, which is similar to the genus Photobacterium (39.3-42.0 $\mathrm{mol} \%)$, but is $20 \mathrm{~mol} \%$ lower than the genus Hyphomicrobium (59-67 mol\%). The cellular fatty acids of $H$. indicum are $16: 0,16: 1$ and $18: 1$ as the major components, and the
Table 2. The fatty acid composition of $H$. indicum and reference strains of the genera Photobacterium and Hyphomicrobium

Values are percentages of total fatty acids. Strains: 1, Photobacterium angustum; 2, P. damselae; 3, P. leiognathi; 4, P. phosphoreum; 5, P. profundum; 6, Hyphomicrobium vulgare; 7, H. methylovorum; 8 , H. indicum.

\begin{tabular}{|lrrrrrrrr|}
\hline Fatty acid & $\mathbf{1}$ & $\mathbf{2}$ & $\mathbf{3}$ & $\mathbf{4}$ & $\mathbf{5}$ & $\mathbf{6}^{*}$ & $\mathbf{7}^{*}$ & $\mathbf{8}$ \\
\hline $12: 0$ & 6 & 4 & 5 & 6 & 2 & - & - & 4 \\
$12: 0$ 3-OH & 8 & 6 & 6 & 9 & 5 & - & - & 2 \\
$14: 0$ & 3 & 5 & 7 & 11 & 3 & - & - & 7 \\
$14: 1$ & 1 & 2 & 1 & 1 & 3 & - & - & 1 \\
$14: 0$ 3-OH & 3 & 2 & 2 & 1 & - & 3 & 2 & - \\
$15: 0$ iso & - & - & - & - & 2 & - & - & 1 \\
$15: 0$ & 2 & 3 & 2 & - & 1 & - & - & 2 \\
$16: 0$ iso & - & - & - & - & 15 & - & - & 1 \\
$16: 0$ & 19 & 20 & 24 & 25 & 9 & 3 & 2 & 26 \\
$16: 0$ 3-OH & - & - & - & - & - & 2 & 3 & - \\
$16: 1$ & 36 & 31 & 34 & 40 & 32 & - & - & 41 \\
$17: 0$ iso & - & - & - & - & - & - & - & 1 \\
$17: 0$ & 3 & 2 & 2 & - & - & - & - & 1 \\
$17: 1$ & 1 & 1 & 1 & - & - & - & - & - \\
$18: 0$ & 2 & 2 & 2 & 1 & 1 & 3 & 8 & 1 \\
$18: 1$ & 17 & 23 & 15 & 3 & 9 & 85 & 74 & 3 \\
$19: 0$ cyclo & - & - & - & - & - & - & 2 & - \\
$20: 5 \omega 3 c$ & - & - & - & - & 13 & - & - & - \\
& & & & & & & & \\
\hline
\end{tabular}

${ }^{*}$ The total fatty acid composition included an unknown peak (Urakami \& Komagata, 1987). Some data were from Nogi et al. (1998). 


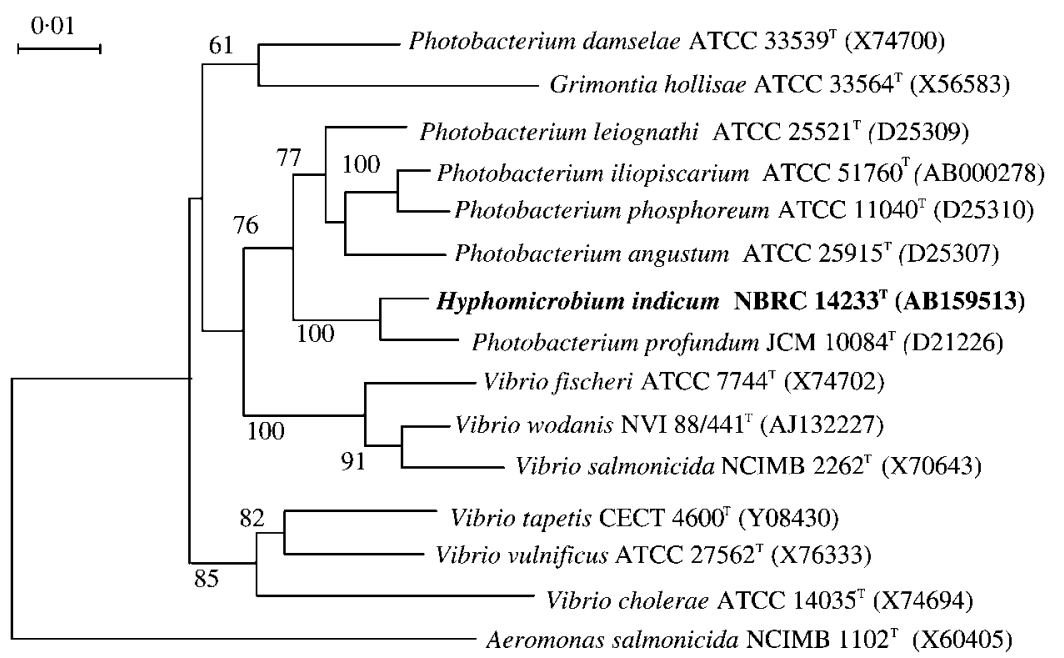

Fig. 1. Neighbour-joining $16 \mathrm{~S}$ rRNA gene phylogenetic tree showing close relationships of $H$. indicum and the genus Photobacterium of the $\gamma$-Proteobacteria. Aeromonas salmonicida was used as the outgroup. Numbers at the nodes indicate the percentages of occurrence in 100 bootstrapped trees; only values greater than $60 \%$ are shown. hydroxy fatty acids contain 12:0 3-OH and 14:0 3-OH. This composition is similar to that of members of the genus Photobacterium, but can be differentiated from members of the genus Hyphomicrobium, which include large amounts of $18: 1$, and the hydroxy fatty acids contain $14: 03-\mathrm{OH}$ and 16: 0 3-OH (Table 2).

Based on phylogenetic analyses of the 16S rRNA gene sequence, $H$. indicum is most closely related to the deep-sea barophilic bacterium (growth at pressures up to $70 \mathrm{MPa}$ ) P. profundum (Nogi et al., 1998), and formed a distinct monophyletic clade with $100 \%$ bootstrap support (Fig. 1). Molecular phylogeny deduced from a single locus may be unreliable due to the stochastic nature of base substitutions or rare horizontal gene-transfer events. Consequently, to identify further a reliable evolutionary position of $H$. indicum, the DNA gyrase gene gyrB, which has a higher molecular evolution rate than the 16S rRNA gene, was selected as another phylogenetic marker. The phylogenetic analyses based on the $g y r B$ gene sequence also revealed that $H$. indicum could be placed within the genus Photobacterium of the $\gamma$-Proteobacteria, with a similarity of $82.6 \%$. These reliable phylogenetic studies reflect that $H$. indicum has a close evolutionary relationship to the genus Photobacterium (Fig. 2). When comparing the 16S rRNA gene sequences of $H$. indicum and species of Photobacterium, we found that only $P$. profundum had a unique signature nucleotide sequence ( $5^{\prime}$-TTCATTACGAGCGG-3') at positions 345359 according to the Escherichia coli numbering system (Brosius et al., 1978). The 16S rRNA gene sequence similarity level $(96 \cdot 9 \%)$ between $H$. indicum and $P$. profundum was found to be within the common index of $16 \mathrm{~S}$ rRNA gene sequences for species-level differentiation (Gillis et al., 2001). In contrast, H. indicum and P. profundum can easily be differentiated by their phenotypic characteristics: morphology, optimum growth temperature, catalase, oxidase, production of $\mathrm{H}_{2} \mathrm{~S}$ and sucrose utilization. As such, they do not belong to the same species.

Based on the phylogenetic, phenotypic and chemotaxonomic distinctions from other species of the genus Hyphomicrobium and the similarity to the genus Photobacterium, we propose that $H$. indicum should be transferred to the genus Photobacterium as Photobacterium indicum comb. nov.

\section{Description of Photobacterium indicum comb. nov.}

Photobacterium indicum (in' di.cum. M.L. neut. adj. indicum named after the bacterium isolated from the Indian Ocean).

Basonym: Hyphomicrobium indicum Johnson and Weisrock 1969.

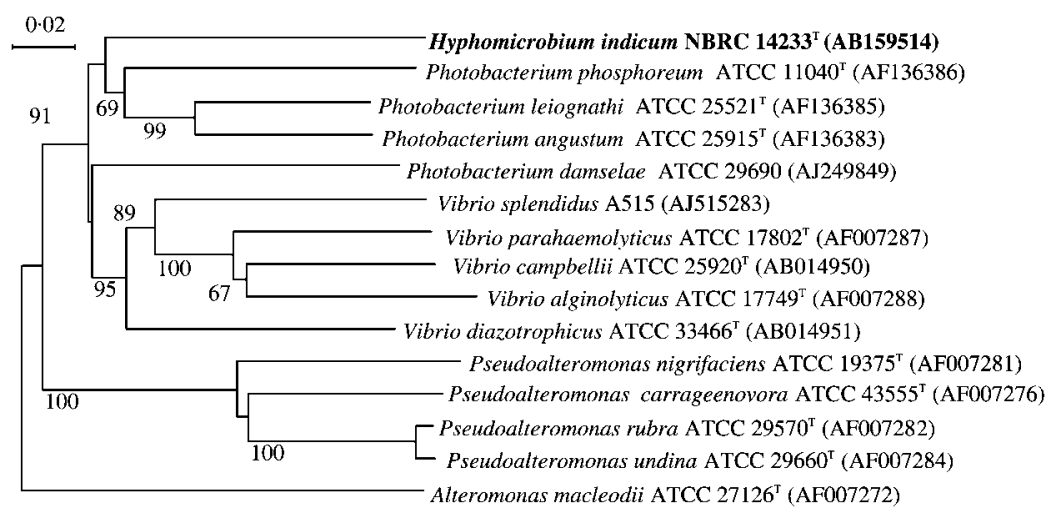

Fig. 2. Neighbour-joining gyrB phylogenetic tree showing the position of $H$. indicum within the genus Photobacterium of the $\gamma$ Proteobacteria. Alteromonas macleodii was used as the outgroup. Numbers at the nodes indicate the percentages of occurrence in 100 bootstrapped trees; only values greater than $60 \%$ are shown. 
The pleomorphic cells appear rod- or coccus-shaped, being $0 \cdot 7-1 \cdot 0 \mu \mathrm{m}$ in width and $2 \cdot 0-6 \cdot 0 \mu \mathrm{m}$ in length. Colonies are yellow. There is motility with polar monotrichous flagella. Growth occurs at $4-25^{\circ} \mathrm{C}, \mathrm{pH} 4 \cdot 5-9 \cdot 5$. Acid is produced from glucose, and the cells can use glucose, sucrose and maltose for fermentation, but cannot use lactose, arabinose, gelatin, casein or starch. Positive tests regarding biochemical characteristics obtained with indole, nitrate and $\mathrm{H}_{2} \mathrm{~S}$. Negative reactions for enzyme activity and antibiotic susceptibility obtained with urease, catalase, oxidase, lysine decarboxylase, erythromycin, tetracycline, penicillin and pteridine; positive reactions obtained with phenylalanine deaminase, chloromycetin, neomycin, kanamycin, novobiocin and streptomycin. The cellular fatty acids are 16:0,16:1 and 18:1 as the major components, and the hydroxy fatty acids contain $12: 03-\mathrm{OH}$ and $14: 0$ $3-\mathrm{OH}$. The major quinone system is ubiquinone Q-8. The $\mathrm{G}+\mathrm{C}$ content of the DNA is $40 \mathrm{~mol} \%$. Based on the phylogenetic analyses of the 16S rRNA and gyrB gene sequences, the bacterium is closely related to the genus Photobacterium of the $\gamma$-Proteobacteria.

The type strain is NBRC $14233^{\mathrm{T}}$ (=ATCC $19614^{\mathrm{T}}$ ), isolated from sea mud at a depth of $400 \mathrm{~m}$.

\section{References}

Borodina, E., Kelly, D. P., Schumann, P., Rainey, F. A., Ward-Rainey, N. L. \& Wood, A. P. (2002). Enzymes of dimethylsulfone metabolism and the phylogenetic characterization of the facultative methylotrophs Arthrobacter sulfonivorans sp. nov., Arthrobacter methylotrophus sp. nov., and Hyphomicrobium sulfonivorans sp. nov. Arch Microbiol 177, 173-187.

Brosius, J., Palmer, M. L., Kennedy, P. J. \& Noller, H. F. (1978). Complete nucleotide sequence of the $16 \mathrm{~S}$ ribosomal RNA gene from Escherichia coli. Proc Natl Acad Sci U S A 75, 4801-4805.

Felsenstein, J. (1985). Confidence limits on phylogenies: an approach using the bootstrap. Evolution 39, 783-791.

Gillis, M., Vandamme, P., De Vos, O., Swings, J. \& Kersters, K. (2001). Polyphasic taxonomy. In Bergy's Manual of Systematic Bacteriology, 2nd edn, pp. 43-88. Edited by D. R. Boone, R. W. Castenholz \& G. M. Garrity. London: Springer.

Hirsch, P. (1974). Budding bacteria. Annu Rev Microbiol 28, 391-444. Hirsch, P. (1989). Genus Hyphomicrobium Stutzer and Hartleb 1898, $76^{\mathrm{AL}}$. In Bergey's Manual of Systematic Bacteriology, 9th edn, vol. 3, pp. 1897-1904. Edited by J. T. Staley, M. P. Bryant, N. Pfennig \& J. G. Holt. Baltimore: Williams \& Wilkins.

Holm, N. C., Gliesche, C. G. \& Hirsch, P. (1996). Diversity and structure of Hyphomicrobium populations in a sewage treatment plant and its adjacent receiving lake. Appl Environ Microbiol 62, 522-528.

Johnson, R. M. \& Weisrock, W. P. (1969). Hyphomicrobium indicum sp. nov. Hyphomicrobiaceae douglas. Int J Syst Bacteriol 19, 295-307.
Kimura, M. (1980). A simple method for estimating evolutionary rates of base substitutions through comparative studies of nucleotide sequences. J Mol Evol 16, 111-120.

Layton, A. C., Karanth, P. N., Lajoie, C. A., Meyers, A. J., Gregory, I. R., Stapleton, R. D., Taylor, D. E. \& Sayler, G. S. (2000). Quantification of Hyphomicrobium populations in activated sludge from an industrial wastewater treatment system as determined by 16S rRNA analysis. Appl Environ Microbiol 66, 1167-1174.

McDonald, I. R., Doronina, N. V., Trotsenko, Y. A., McAnulla, C. \& Murrell, J. C. (2001). Hyphomicrobium chloromethanicum sp. nov. and Methylobacterium chloromethanicum sp. nov. chloromethaneutilizing bacteria isolated from a polluted environment. Int J Syst Evol Microbiol 51, 119-122.

Nogi, Y. Masui N. \& Kato, C. (1998). Photobacterium profundum sp. nov., a new, moderately barophilic bacterial species isolated from a deep-sea sediment. Extremophiles 2, 1-7.

Rainey, F. A., Ward-Rainey, N., Gliesche, C. G. \& Stackebrandt, E. (1998). Phylogenetic analysis and intrageneric structure of the genus Hyphomicrobium and the related genus Filomicrobium. Int J Syst Bacteriol 48, 635-639.

Roggentin, T. \& Hirsch, P. (1989). Ribosomal RNA cistron similarities among Hyphomicrobium species and several other hyphal, budding bacteria. Syst Appl Microbiol 11, 140-147.

Saitou, N. \& Nei, M. (1987). The neighbor-joining method: a new method for reconstructing phylogenetic trees. Mol Biol Evol 4, 406-425.

Stackebrandt, E. R. G., Fischer, A., Roggentin, T., Wehmeyer, U., Bomar, D. \& Smida, J. (1988). A phylogenetic survey of budding, and/or prosthecate, non-phototrophic eubacteria: membership of Hyphomicrobium, Hyphomonas, Pedomicrobium, Filomicrobium, Caulobacter and "Dichotomicrobium" to the alpha-subdivision of purple non-sulfur bacteria. Arch Microbiol 149, 547-556.

Swofford, D. L. (1998). PAUP* Phylogenetic analysis using parsimony ( ${ }^{*}$ and other methods), version 4 . Sunderland, MA: Sinauer Associates.

Thompson, J. D., Higgins, D. G. \& Gibson, T. J. (1994). CLUSTAL W: improving the sensitivity of progressive multiple sequence alignment through sequence weighting, position specific gap penalties and weight matrix choice. Nucleic Acids Res 22, 4673-4680.

Tsuji, K., Tsien, H. C., Hanson, R. S., DePalma, S. R., Scholtz, R. \& LaRoche, S. (1990). 16S ribosomal RNA sequence analysis for determination of phylogenetic relationship among methylotrophs. $J$ Gen Microbiol 136, 1-10.

Urakami, T. \& Komagata, K. (1987). Characterization and identification of methanol-utilizing Hyphomicrobium strains and a comparison with species of Hyphomonas and Rhodomicrobium. J Gen Appl Microbiol 33, 521-542.

Xie, C. \& Yokota, A. (2003). Phylogenetic analysis of Lampropedia hyalina based on the 16S rRNA gene sequence. J Gen Appl Microbiol 49, 345-349.

Yamamoto, S. \& Harayama, S. (1995). PCR amplification and direct sequencing of $g y r B$ genes with universal primers and their application to the detection and taxonomic analysis of Pseudomonas putida strains. Appl Environ Microbiol 61, 1104-1109. 